\title{
Poorly Differentiated Thyroid Gland Carcinoma
}

National Cancer Institute

\section{Source}

National Cancer Institute. Poorly Differentiated Thyroid Gland Carcinoma. NCI

Thesaurus. Code C6040.

An adenocarcinoma arising from the thyroid gland showing only limited evidence of follicular cell differentiation. Microscopically, the adenocarcinoma cells are arranged in insular, solid, and trabecular patterns. There is associated necrosis, and vascular invasion. The prognosis depends on the tumor stage, complete or partial surgical removal of the tumor, and the degree of response to radioactive iodine therapy. (adapted from WHO Tumors of Endocrine Organs, IARC Press, Lyon 2004) 